\title{
Elections and Emerging Citizenship in Cambodia
}

\author{
Astrid Norén-Nilsson
}

At an informal lunch in the company of Cambodian friends in Phnom Penh, our host Sambath surprised us by showing a video of opposition leader Sam Rainsy's return to the Cambodian capital a few days earlier. After four years in self-imposed exile, Sam Rainsy had returned only nine days ahead of the July 2013 national elections, as president of the newly formed Cambodia National Rescue Party (CNRP). The video documented the fervour of the welcome offered by a sea of supporters, lining the streets from Pochentong Airport across the city to the so-called Freedom Park, the designated spot for demonstrations. What surprised our lunch company was not the (now familiar) images themselves, but rather that the video was being shown at the home of a security guard at Phnom Penh's O'Russey market. The guard, who was officially required to be a member of the incumbent Cambodian People's Party (CPP) and had the task of monitoring the political allegiance of market vendors, had decided to purchase the DVD from one of these vendors regardless, seemingly betraying his political masters. In this chapter, I will reflect on what the security guard's actions may imply about changing notions of citizenship in contemporary Cambodia.

The national elections held on 28 July 2013 were Cambodia's fifth since the reintroduction of a multiparty democratic system, prepared for by the 1991 Paris Peace Agreements (PPA). The Cambodian People's Party (CPP) and its precursor, the Kampuchean People's Revolutionary Party (KPRP), have dominated Cambodian politics ever since 1979, from a one-party socialist republic through to the transition to today's multiparty liberal democratic state of the Kingdom of Cambodia (KOC, 1993-). Though royalist party FUNCINPEC won the first multiparty elections in 1993, the CPP has seen successive electoral triumphs ever since, steadily increasing its vote from $38.2 \%$ in 1993 , to $41.4 \%$ in 1998 , to $47.3 \%$ in 2003 and to $58.1 \%$ in 2008 , while heading successive coalition governments with FUNCINPEC. Having consolidated its power to what seemed an unprecedented extent, the CPP under the leadership of Prime Minister Hun Sen appeared poised to enjoy a landslide victory in the 2013 national elections. The official election results, therefore, took most observers by surprise: the CPP suffered a sharp drop in support, winning only $48.83 \%$ of the vote, while the CNRP, a newly formed coalition between the two main opposition parties, came in a close second at $44.46 \%$. The CNRP has 
refused to acknowledge the official election results, and claims to be the real winner of the elections.

While it is clear that Cambodia is going through some major social and political changes at the moment, their nature and direction remain elusive. Strikingly, they appear to be intimately tied up with popular living conditions and access to resources. The Cambodian state is structured by interlocking pyramids of competing patron - client networks ( $k$ hsae), and political power stems from the ability to fulfil the material aspirations of clients (Heder 1995: 425-429). Since economic liberalization in the late 1980s, a hybrid neopatrimonial administration has emerged, whereby informal patron - client power dynamics have mixed with formal bureaucratic power. Power is highly centralized to political figures and central ministries exercising control over resources, but is maintained by political support from rural bases secured through the distribution of material gifts and physical infrastructure (Pak et al., 2007: 57-58). The CPP has relied on such gift-giving practices throughout the era of multiparty democracy as a defining characteristic of the party's political project. This is integral to shoring up popular allegiance and electoral support. The democratic opposition, on the other hand, has campaigned on an anti-corruption agenda, similar to that of many other Southeast Asian democratic parties. They consider gift-giving practices as vote-buying, and use rights-based language to challenge these.

The legitimacy of these competing models of provision in Cambodia remains poorly understood. Whilst a discourse of rights is firmly rooted, it is unclear whether voters are now challenging the current political economic order by claiming their right to resources, or are simply seeking new avenues to access resources - irrespective of the terms. This chapter attempts to approach the question of whether, and if so, how, the electoral surge of the opposition relates to the legitimacy of different models of provision. In doing so, it takes up this volume's invitation to examine how the institution of electoral democracy relates to the politics of patronage and clientelism. More specifically, it questions whether an 'unremitting preference of voters for clientelistic exchanges' such as that described in the introductory chapter, can be identified, and to what extent political clientelism can be understood as an alternative form of democratic accountability. I start by examining competing elite-defined conceptualizations of democratic citizenship relating to clientelistic practices and a competing rights agenda, and then reflect upon how such ideas played out in the 2013 national elections. Tracing their role in the political parties' campaign discourses, strategies and post-election analyses, I draw on ethnographic data to offer an account of corresponding popular values and practices. I then assess what this tentatively says about emerging forms of citizenship in Cambodia. 


\section{Emerging Forms of Citizenship in Cambodia}

In Cambodia, just as in many other Southeast Asian countries, the notion of citizenship (sânheat) carries little significance beyond that of designating one's legal status. A far more central notion in domestic political discourse is that of the nation (cheat), posited on the presumption of a shared identity to which competing political values are attached, which generally outshines and, often, stands in outright conflict with the legalistic notion of citizenship. ${ }^{1} \mathrm{~A}$ range of competing models of the 'ideal nation' - outlining particular relations between the political leadership and the general populace, all envisaged as 'democracy' that date back to before the 1953 achievement of national independence, are propagated by political parties. A defining characteristic of these different models is the terms of access to resources through which the populace is to obtain property, security and welfare. By studying the everyday practices, values and attitudes that characterize concrete interactions between citizens and the public authorities, we can establish a fresh perspective for conceptualizing the transforming legitimacy of different models of provision, the ideal political order and, by extension, emerging forms of Cambodian citizenship.

In Cambodian political discourse, election promises have been understood to centre on buzzwords such as 'democracy', 'human rights', and 'justice' often overlapping between parties and seemingly void of meaning (Hughes 2002: 169). This scenario has baffled observers, who expected electoral competitors to phrase their programmes in the language of ideology. ${ }^{2}$ Yet arguably, political competition is bound up with each party or party leader declaring to be the genuine representative of an idealized imagining of the Cambodian nation. In seeking to forge exclusive links between themselves and the nation, political actors have offered solutions centred on the provision of welfare and access to state resources - each bestowing a different meaning to notions like democracy. Interpretations of citizenship, as practiced and perceived, are tied to such wider ideas and are not solely confined to the individualistic rightsclaiming typically celebrated in citizenship literature.

1 The latter case is exemplified by the political party The Cambodian Citizenship Party (Konâbâk Sânheat Kampuchea) which competed in the 2013 national elections. Purporting to represent the interests of all those holding Cambodian citizenship - including those of Vietnamese ethnicity - it was therefore primarily considered to be pro-Vietnamese.

2 Joakim Öjendal and Mona Lilja (2009:303) note that 'the idea that the existence of competing party ideologies is one of the cornerstones of liberal democracy has not taken root in Cambodian society'. 
Partha Chatterjee has influentially argued that we need to reconceptualize how developmental states and their populations in the Global South interact. Citizens in the postcolonial world primarily aspire to access state resources little does it matter that these are typically granted as 'exceptional entitlements' instead of full citizenship rights (Chatterjee 2004, 2011). Employing Chatterjee's notion of 'political society' as the sphere where such interactions take place, Andrew Walker (2012) has attempted to redefine rural political behaviour in Thailand which, like its neighbour Cambodia, is set in a clientelist, gift-giving economy. Walker argues that Thai rural voters are informed by local values, which recast practices typically dismissed under the label of 'clientelism' as important characteristics of legitimate political power. Applied to Cambodia, the notion of 'political society' adequately recognizes the centrality of access to benefits, welfare and state resources for emerging concepts of citizenship and democracy. Yet, the Cambodian case also challenges the certainty that populations across the postcolonial world are content with exceptional access to resources - such as the presentation of gifts - rather than full citizenship rights.

A sharp dichotomy between a Western rights-based type of citizenship and a postcolonial one based on patronage does not only defy empirical evidence, but also runs the risk of 'othering' Cambodian forms of citizenship as necessarily clientelist. Schaffar (Chapter 10 in this volume) has identified similar trends in the case of Thailand. Crucially, popular access to benefits, welfare and resources, which patterns of citizenship revolve around, is often negotiated not between populations and states, but between the former and 'twilight institutions' (coined so by Christian Lund) - organizations that are not legally recognized as part of the state but nonetheless exercise public authority. These groups of institutions are said to operate in the 'twilight' between state and society and the public and private spheres. Public authority is here 'processually' formed in the sense that when 'an institution authorizes, sanctions, or validates certain rights, the respect or observance of these rights by people... constitutes recognition of the authority of that particular institution' (Lund 2006: 675). Recognition or rejection takes place in day-to-day social encounters between various forms of public authority and ordinary people. Lund, therefore, invites us to approach the phenomenon of public authority from the perspective of how particular issues (such as security, justice, development or taxation) are governed by a variety of actors, rather than to see these as stemming from the single source of the state (Lund 2006: 682). In Cambodia, twilight institutions are crucial for providing citizens with resources such as security, welfare and property. 
Studying changing everyday values and practices in encounters with public authorities, often of a twilight kind, can therefore instruct us in several ways. These changes can be read as a transforming set of popular political values. ${ }^{3}$ This sheds light not only on the legitimacy of Cambodia's current political economic order, but also of various elite political projects, Cambodian state - society relations in general, and the ideal model of relations with political leadership as envisaged by its populace. Interactions between ordinary people and public authorities also inform us about emerging notions of citizenship - giving us an understanding of whether the populace is primarily seeking to maximise what the state can provide, or if there is a desire to formalize this access to resources. As people in twilight institutions move in and out of state and society, and between public and private spheres, these interactions offer an insight into ongoing negotiations for different models of resource provision.

\section{The Politics of Gift-Giving and Democratic Citizenship in Cambodia}

The provision of benefits and resources to the populace has been central to historical conceptualizations of legitimate power in Cambodia. In the era of multiparty politics, contemporary political party projects have reinvented such historically inherited ideas inside the framework of a radically new political economy, mobilizing them to their own political ends. Though democratic legitimizations in Cambodia are typically understood incorrectly as external in nature, these ideas have been at the foundation of competing political projects phrased in the language of democracy - intended for and vocally propagated to the domestic population. Ideas of how resources are to be distributed to the population are central to competing domestic discourses of democracy in varying ways.

The incumbent Cambodian People's Party (CPP) has relied on gift-giving as the backbone of their domination of Cambodian politics throughout the era of multiparty democracy. In CPP discourse and practice, social and economic development is presented in the form of gift-giving rather than in terms of state accountability associated with taxation. These gift-giving practices

3 In the context of Thailand, Andrew Walker (2008:87) has referred to such local values that inform the everyday politics of elections as making up a 'rural constitution': an uncodified set of political values which 'regulates, constrains, and legitimates the exercise of political power'. 
have inserted patronage logics into post-reform Cambodia's democratic system in complex ways (Hughes 2006), with much service provision taking place through twilight institutions. CPP working groups (krom kar ngear) are in charge of distributing donations from the party to rural communities, what is known as the choh moulothan ('going down to the base') strategy. This strategy originated in the 1980s, when party cadres brought pro-socialist, anti-Khmer Rouge propaganda to the grassroots. However, when the multiparty democratic system was introduced, its meaning changed to the bringing of donations, which were understood to increase in the event of CPP electoral victory (Un 2005:221-222). Since the working groups are directly associated with voter mobilization at the local level, this has been a crucial strategy for ensuring the CPP's continued hold on power. ${ }^{4}$ The twilight character of the CPP working groups is clearly evident here: they present developmental assistance as coming from the party and sponsoring business partners rather than from the state, and yet have come to constitute an important channel of provision substituting for the state in rural areas. Their achievements are frequently broadcast in the media, but they hold no civic accountability and there is no publicly accessible documentation of their work.

Another important channel of provision is the Cambodian Red Cross (Kakâbat Krohom Kampuchea), headed by First Lady Bun Rany. The CRC has, since its beginning, enjoyed unique recognition from the government as its auxiliary and a mandate as a quasi-governmental organization, basing its work on the help of volunteers to distribute aid to victims of natural disasters, soldiers, orphans, et cetera (Men and Dickens 2005:31). ${ }^{5}$ Under the presidency of Bun Rany, the CRC has become increasingly publicly exalted, in ways that emphasize the distinctly royal overtones that her work for this (originally royal) organization carries. As head of the CRC, Bun Rany's association with caretaking and healing intersects with the conceptual and historical role of royals on a number of levels. ${ }^{6}$ Paralleling the consolidation of power by Hun Sen and

4 Each of Cambodia's districts has a working group. In this top-down structure, a deputy prime minister is responsible for the province level, a minister or secretary of state (ss) for the district level, an ss or ministry director general for the commune level, and a ministry director (or equivalent rank) for the village level. The working group typically visits their district on the weekend, together with sponsoring business partners, to offer developmental assistance.

5 Originally founded in February 1955 as the Khmer Red Cross Society (Samokom Cheat Kakâbat Krohom Khmer), the organization was renamed the Cambodian Red Cross (CRC) in 1979.

6 Bun Rany replaced Princess Norodom Marie, then spouse of FUNCIN PEC party leader Prince Norodom Ranariddh, as president of the Red Cross in 1998, following the July 1997 events which ousted Ranariddh from his post as first prime minister. On the historical association between kingship and healing, see Thompson (2004). 
his network, her presidency has firmly integrated practices of gift-giving into personalized claims to embody nation-building in line with historical conceptualizations of kingship.

These strategies of provision are an integral part of the political project, democratic vision, and legitimizing discourse propagated by the CPP to the domestic population. The CPP-led regime, under Prime Minister Hun Sen, is typically understood not to have put forth a self-identified political identity to fill the shoes of the previous Marxist-Leninist identity that was pushed aside with Hun Sen's rise within the party - when pragmatic technocrats came to replace Marxist-Leninist ideologues in government (see, for example, Slocomb 2006:395). Yet, next to appeals for liberal democracy, Prime Minister Hun Sen claims 'populism' to be the political identity of his regime, and has advanced the concept of 'people's democracy' (pracheathipatey pracheachon) as the base of CPP policies and his own political thinking. ${ }^{7}$ Hun Sen has provided the following definition of 'people's democracy':

What I try to do is to provide the best service for the people, the majority of the people who are poor. When we started the struggle to liberate the citizenry, we targeted the people to make the majority of the people rich after the genocidal regime. With bare hands we made sure that people would start living again and enjoy better living conditions. Our policy towards farmers is that we have never claimed tax from them. I have told my colleagues not only not to tax farmers, but also that we must intervene to help the people. We have to build infrastructure for the people, including irrigation, roads, canals, houses, schools, and clinics.... These are some of the points related to the basis of our policies, that is, people's democracy.

HUN SEN, interview by the author, 29 August 2011

The notion of 'people's democracy' makes claims of popular representation through a truly national form of democracy, which deviates from the liberal democratic model. First elaborated by Prime Minister Hun Sen during the People's Republic of Kampuchea (1979-1989), it can be understood to provide a discursive and conceptual bridge in regime identity from the one-party socialist republic of the PRK to the KOC era (1993-) of capitalist transformation within a multiparty democratic framework. 'People's democracy' in the кос

7 This has been overlooked by existing scholarship, despite the recurrence of these notions in public discourse (see, for example, Hun 2005, 2007).

8 Hun Sen first developed the notion in his doctoral thesis 'Lokkhânah pises day laek nei domnaurkar padevott Kampuchea' (The Special Characteristics of the Progress of the Cambodian Revolution), which written during the PRK-era, discussed the evolution of Cambodian 
has been reoriented to frame the novel regime practices - centred around giftgiving - associated with the transformation into a new political and economic system within the post-1993 framework. ${ }^{9}$ Democracy is made out to form a continuity - linking past and present regime practices - even though its PRKera Marxist-Leninist contents have been wiped away. Portrayed as the very foundation of the CPP-led regime's political agenda, gift-giving practices have thereby become central to the regime's version of democracy as propagated to the general public.

The notion of legitimate leadership as residing in the ability to provide for the well-being of the population has also been constructed by a second main political camp in the KOC - the royalists. Entangled with historical conceptualizations of Khmer Buddhist kingship (see Thompson 2004), this notion was given its modern shape in Prince Sihanouk's 'People's Socialist Community' (Sangkum Reastr Niyum 1955-70); Cambodia's first post-independence regime which assumed a rosy glow in the post-1993 reunited kingdom. This was not solely a historical legacy easily appropriated by the C PP (cf. Frings 1995; Hughes 2006), but was also made a cornerstone of the post-1993 reinvention of royalist democracy. Under the label of 'the social opening', identified by long-term FUNCINPEC leader Prince Norodom Ranariddh as a doctrinal basis of 'Cambodian democracy' during the Sangkum, royal provision for and protection of the population remained central to Ranariddh's vision of what democracy must mean in the KOC (Norodom 1998:133). The social opening was displayed in how FUNCINPEC engaged in development activities, including practices of gift-giving, which were framed as directly modelled on Sihanouk's activities in the past. Yet, although the royalists propagated a pleasant vision of royalist democracy, they lacked the material base to put this into practice. Seen from this perspective, FUNCINPEC'S outmanoeuvring by the CPP as providers of benefits not only stripped them of the gratitude of beneficiaries, but also resulted in a 'democratic deficit' for the royalists. The long and steady decay of FUNCINPEC, since the party's 1993 electoral victory, appears to have reached its end-point with the 2013 elections when, for the first time, the party failed to win any seats.

The main challenge to the CPP model of provision has come from a third group of party political actors, the Democrats. This group considers provision

regimes and state - society relations since the French protectorate onwards. In this re-reading of Cambodian history using Marxist-Leninist concepts and categories, democracy was firmly integrated as part of revolutionary history as the unchanging goal of 13 decades of a Cambodian revolutionary quest. Parts of the thesis were published as 13 tusevott nei domnaur Kampuchea [13 Decades of Cambodia's Evolution], Hun (1991).

9 Hughes (2006:469) traces the practice of gift-giving to the beginning of Cambodia's political and economic reform process, around 1989. 
for popular needs primarily in terms of the satisfaction of the 'people's will', which the Cambodian democratic project has posited as its very raison d'être. Democrats have, therefore, engaged in a range of strategies to identify the socio-economic needs of the people by learning about their living conditions what can be understood as their fundamental imagining of how to democratically relate to the nation. To trigger change, democrat leaders would have to insert themselves into ordinary people's realities, allowing them to channel their demands and thus empower them. The purpose was to raise all members of society to equal status as rights-bearing citizens, considered to be a precondition for true democracy. These strategies have been all the more important since the Cambodian democratic project's claim to popular representation has been partly contradicted throughout its history by its elite-driven nature, entailing fundamental problems of connecting with the rural masses it has purported to represent (cf. Chandler, 1991:30; Corfield 1994:10-11; Hughes 2009:35). Alienated from the electorate by their elite and transnational backgrounds, it has been deeply problematic for KOC-era Democrats that the CPP's penetration to the local level has given the party the near-exclusive ability to identify and satisfy people's actual needs. This manifests the closeness, or even intersection, of the CPP and democratic discourses, resulting from their shared focus on provision.

The Democrats imagine democracy to transcend the implementation of an ideology or doctrine, and to be concerned with more basic questions of the relationship between the people and the political leadership. The terms by which the population accesses resources has been highlighted as paramount. CNRP President Sam Rainsy and his supporters have charged that the CPP-led government pursues a particular strategy to control the populace, summed up as the 'three k's': khlach (fear), khlean (hunger), and khlov (ignorance)..$^{10}$

Under the rubric of khlean (hunger), Sam Rainsy has accused the CPP of maintaining a 'link of subjection' with the people through their gift-giving practices:

10 The 'three k' has been identified by some as a Khmer Rouge strategy to ensure complete control of the populace. Sam Rainsy and other Democrats have repeatedly charged that the CPP regime purposely emulates this model. In his 2008 autobiography, Sam Rainsy thus identifies, in contemporary Cambodia, the presence of widespread fear, through CPP-led politically motivated intimidation, threats and constraint forming a weapon of political domination; hunger, charging that the CPP prefers to maintain a link of subjection' with the people by offering food donations rather than creating viable jobs; and ignorance, charging that the CPP does not invest sufficiently in education, purposely resulting in continued high levels of rural illiteracy and the absence of social and political conscience and critical thought Sam 2008: 228-9). 
Khlean - [under Khmer Rouge] they [the people] would die of starvation. But Hun Sen's people are making people poor. They lose their land, their fishing zone, [they have] poor salaries like factory workers, with commercial monopolies causing an increase in the price of commodities. This is the new system to control the people through the economy, through the basic needs of survival. Then they depend on donations, on handouts, and forget the national issues. This is why the fight against corruption, the fight to improve living conditions, to allow people to live with job creation, [so that] you depend on your salary, and not on handouts - all these are interrelated. Then the human spirit can thrive because you are not prisoner of your stomach.

SAM RAINSY, interview by the author, 24 April 2012

Effectuating social and political change requires a change from the prevailing 'beggar mentality' to a newly-established 'culture of citizenship', according to Sam Rainsy. He felt that the citizenry would free themselves of the blurred vision that the policies of khlach, khlean, khlov has imposed on them, and clearly perceive of their interests and rights as citizens, if only they would be allowed to develop critical thinking. Democrat leaders routinely express their belief in the necessity of profound changes in Cambodian popular mentality to achieve this culture of citizenship - often invoking Western models - as seen in the following quotes:

To change the system peacefully, you need to change the mentality of the people. In Cambodia, it is like the traditional, ancient states. We need to educate and say - you are the people, the masters of the country's destiny. Every day, I have to educate the people that I meet to make them change the mentality. If we speak about democracy, they understand nothing. That is my opinion - we need to change people's mentality and especially that of the youth. We need to educate them about anticorruption, how to fulfil their tasks as citizens. I have the technique, I am a pedagogue.

HO VANN, interview by the author, 26 March 2010

I think Cambodian people are learning what democracy is all about. We have the exposure to Western thinking and try to introduce it to our members. Then it is up to them to decide, not us.

SON CHHAY, interview by the author, 23 March 2010

Envisaging democratization in strongly didactic terms as a change of mentality is widespread in regional democratising contexts. Often, elites draw on 
Western democratic theory to insert new notions of citizenship in order to remould the relationship between populations and the state. In Thailand, such concepts came to underpin what Michael Connors (2003) has characterized as 'democrasubjection', referring to the employment of elite-defined liberal democracy as a disciplining practice to secure hegemony over the population. Although in Cambodia there was never one hegemonic, national ideology of democracy such as that which Connors identifies in Thailand, one can certainly see similarities with the project of Cambodian self-identified democrats. The elites are needed to steer this process of a change in mentality, and they continue to define what is meant by the 'common good', which all ideal citizens are envisaged to work towards. In this sense, democratic elites primarily represent a 'future nation' which they have actively tried to create and shape, rather than one that already exists. In Thailand, elites share an interpretation of popular (rural) political behaviour as dictated by money politics, and therefore refuse to recognize the democratic legitimacy of the electoral choices made by the general populace. ${ }^{11}$ Likewise, in Cambodia, democrats believe that the vision of the general populace is blurred by the 'three $\mathrm{k}$ ', which leads to profoundly illegitimate electoral outcomes. By contrast, however, Cambodian democrats have put their efforts into moulding rural political choices through delegitimizing clientelistic exchanges in the eyes of the electorate.

Though purporting to represent grassroots concerns, these competing democratic discourses were articulated from above. The nature of Cambodian democracy and its appropriate model of provision has largely remained an intra-elite debate - a major reason for this possibly being the sheer ignorance of the elite regarding the political preferences of the electorate. Caroline Hughes (2001:298) has drawn attention to the social and political opacity of Cambodia's post-war rural electoral heartland' and refers to Cambodian voters as the 'silenced majority'. She highlights that 'very little is known' about the demographics of Cambodian voter preferences, so that 'political parties continue to operate blindly in this key site of democratic politics'. Ever since the first democratic elections in 1993, voters have been encouraged to not speak openly about their political preferences (Hughes 2001:303-304). Studying popular perceptions and practices of accessing state resources, therefore, sheds muchneeded light on the levels of legitimacy that elite discourses of democracy hold

11 Walker (2012:91) summarizes this model of rural political behaviour as having three components: that rural voters have little interest in policy issues and vote for those who can deliver immediate benefits; that they are readily swayed by vote-buying; and that electoral mobilization takes place through hierarchical ties of patronage whereby local figures deliver votes to political masters. 
in society, and the competing understandings, reinterpretations and or renegotiations there. These debates are central to the contested nature of emerging forms of democratic citizenship in Cambodia.

\section{July 2013 Elections}

The manner of resource distribution has thus been the defining feature to distinguish competing political party projects throughout the multiparty democratic era, pitting the CPP and royalist championing of gift-giving practices against the condemnation of this by the democratic opposition parties. Although this issue has had a constant presence, it was called into question more aggressively than ever before during the campaign for the July 2013 national elections. During this time, the CNRP made a concerted effort to bring down the legitimacy of CPP gift-giving practices, which they perceived as votebuying. In their analysis, CNRP leaders later credited this conscious strategy with their subsequent strong gains (Mu Sochua, interview by the author, 20 November 2013).

Most plainly, the effort to discredit gift-giving practices was expressed in the ubiquitous CNRP campaign slogan: 'My gasoline, my motorbike, my money, my morale, save my nation. Change! Change! Change!' This slogan referenced how CNRP campaign rally participants would ride their own motorbikes, spending their own hard-earned money on gasoline, that way expressing their unselfish commitment towards the nation. Its obvious target was the CPP rally participants, who conversely received money for their participation, and typically toured on large pick-up trucks provided by the party, which were gaily embellished with coloured lights and equipped with TV screens and bombastic dance music. This slogan was printed on stickers and distributed to participants in the CNRP campaign rallies, many of whom plastered them onto their motorbikes. Its power lay in tying the rejection of gift-giving practices to a general call for change. Change was portrayed as inherently linked to, or directly constituted by, citizens taking pride in spending their own resources for acting on their political conscience, rather than offering political allegiance in return for financial and material support.

By contrast, the CPP's main campaign slogan was a direct appeal for personal loyalty to Prime Minister Hun Sen, and was phrased: 'If you love, if you pity, if you like, if you trust Samdech Hun Sen, vote for the Cambodian People's Party. Voting for the Cambodian People's Party means voting for yourself.' Equally ubiquitous, this slogan was put on campaign posters with a smiling prime minister spread across the country. Expressing the personalization of 
power to the prime minister at the expense of the CPP as a party, this slogan cast service provision as directly dependent on the personal intervention of the prime minister, who would see to it that all those who chose to place their trust in him were provided for.

The CNRP slogan discredited, in particular, the CPP practice of offering campaign rally participants financial compensation, amounting to five us dollar per day. CNRP campaign discourse also questioned CPP campaign funding in general, charging that it came from tax collection appropriated by the CPP. The typical CNRP narrative stated that rally participants collected the daily five US dollar for campaigning for the CPP, only to bring this money to the CNRP donation boxes. In their campaign discourse, the CNRP consistently encouraged the electorate to receive any gifts offered by the CPP, but to stop short of actually voting for the party. The CNRP's routine encouragement of voters to accept whatever they could receive from the CPP reflected a willingness to accept the electorate's dependence on gift-giving rather than to condemn it, but to transform the act of receiving gifts to a subversive one, loaded with the force of covert rejection.

The CNRP, on the other hand, collected donations from campaign rally participants through donation boxes in on-site tents at Freedom Park, the Phnom Penh campaign rally point. Campaign participants were encouraged to make donations in the form of money, food, or any other materials they deemed useful. According to CNRP lawmaker-elect Mu Sochua, the party typically collected 30,000 us dollar per rally day through these boxes $(\mathrm{Mu}$ Sochua, interview by the author, 20 November 2013). The CNRP also pleaded for financial contributions through radio broadcasts stating their account number. The names of donors were then publicly acknowledged on Facebook.

While the CNRP put great emphasis on discrediting the practice of financially compensating campaign rally participants, the party did offer forms of financial support to campaign participants. The CNRP covered transportation for participants travelling from provinces to Phnom Penh's Freedom Park, and provided them with lunch and dinner during their first day of participation. The CNRP also mobilized their funds - much of it donated by Cambodian overseas supporters - to support particular causes, such as supporting those locked in ongoing conflicts with the government. Examples include the victims of land evictions in Phnom Penh's Borey Keila and Boeung Kak communities as well as those injured at post-election demonstration incidents at Kbal Thnal and Steung Meanchey in the suburbs of Phnom Penh. The CNRP also supported communities hit by flooding throughout the country in August to September 2013, and made financial donations to villagers for the Buddhist gift-giving ceremony of Kathen during this period. According to the CNRP, 
these gift-giving practices differed from those of the CPP because target villages were not selected on the basis of whether the party headed the commune, and also that membership of the CNRP was not a criterion to receive gifts. Rather, donations were given to villages with a strong link between the party and the villagers through active MPs. Party representatives in villages would contact the party headquarters when help was required, and the communities most affected would be singled out for support. Whilst the terms of gift-giving were thus said to differ from those of the CPP, the ability to provide was arguably an important contributing cause for the CNRP's electoral gains. Just as CNRP leaders later claimed that the critique of CPP gift-giving practices was prompted by their strong surge in electoral support, they equally acknowledged their increased ability to assist voters through local networks as a crucial element (Mu Sochua, interview by the author, 20 November 2013).

A main factor believed to have contributed decisively to the popularity of the CNRP was the seven-point policy programme that they campaigned on, which focused on raising living standards. The CNRP pledged to fund this programme by using existing domestic revenue and cutting back on corruption to re-appropriate missing revenue from taxes, customs and land concessions. An important part of the programme centred on promising a personal income, with three out of seven points guaranteeing minimum salaries and pensions. Two more points concerned the provision of social benefits, in the form of free healthcare and education, whilst a further two established a minimum price for rice and pledged to lower the prices of oil, fertilizer, electricity and loan interest rates:

1. A monthly pension for individuals aged sixty-five years and older of 40,000 riels ( 10 us dollar).

2. A minimum monthly wage for workers of 600,000 riels (150 Us dollar).

3. A minimum monthly salary for civil servants of $1,000,000$ riels ( 250 US dollar).

4. Farmers guaranteed to receive at least 1,00o riels per kilogram of rice (o.25 Us dollar).

5. Free medical care for the poor.

6. Equal education opportunities and proper employment for youths.

7. A reduction of the prices of oil, fertilisers, electricity and interest rates on loans.

The seven points can be read as promises to secure voters' personal income and access to state resources as a matter of right, rather than as ad hoc gifts. In this sense, they promised to formalize the access to state resources. 
An equally plausible alternative reading is that the seven points guaranteed to increase voters' income, which arguably took precedence over the discussion of whether this was granted as a right rather than an entitlement. Read in this way, this policy platform primarily constituted a pledge to improve voters' personal economy.

From the perspective of the CNRP leadership, their dramatic electoral gains reflected a mixture of both motivations. While gift-giving practices were recognized as forming a part of domestic political culture, the CNRP maintained that the CPP's mistake was to have a complete reliance on such practices without realising that voters were angered by the vast income discrepancy that had developed. Voters would accept gifts if offered, but they were not sufficient to satisfy them. The CNRP aimed to mobilize this existing discontent and transform it into a larger political analysis to eventually make people renounce gift-giving practices and the current economic order, thus planting the seeds of a new political conscience. This was phrased in the language of rights. Rather than simply encouraging the electorate to vote for the CNRP, the party encouraged the electorate to 'vote for your right'. Their subsequent surge in popularity was therefore perceived to derive from a combination of the yearning to secure better living standards and a change of political consciousness. Initially, in this analysis, supporters were motivated by an attempt to secure more personal income, such as those promised by the seven points. Once involved in the CNRP campaign, however, this initial motivation would transform into a changed political consciousness, whereby political activity and participation would be prized over the passive receipt of benefits (Mu Sochua, interview by the author, 20 November 2013).

From the perspective of the CPP, however, their sharp decline in electoral support was interpreted very differently. They believed voters had developed an indifferent attitude towards the CPP's provision of public infrastructure such as roads, bridges and hospitals, which were now starting to be taken for granted. Provisions of this kind quickly became part of everyday life, and voters had forgotten where the initiative and funding for local infrastructure originally came from. A vote for the CNRP, meanwhile, was understood as a vote to obtain more money to put in one's own pockets. Seen from this perspective, the CNRP's seven points were chiefly made up of promises of money to be pocketed individually, and this was what had convinced an increasingly greedy electorate (senior CPP leaders, author's personal communication, November-December 2013).

These respective analyses formed the basis of the two parties' post-election strategies. The CNRP continued to place a strong focus on raising minimum 
salaries, framing this as a right. For example, at a demonstration on the International Human Rights Day in December 2013, Sam Rainsy (2013) claimed that four basic human rights were still lacking in Cambodia: the right to life; the right to decent and dignified living conditions; the right to freedom; and the right to elect political leaders. Salaries, he stated, were integral to both the second and third rights, as a fair salary would guarantee that workers could live in a decent manner and enjoy freedom rights.

The CPP, on the other hand, increased the scale of gift-giving, rather than changing the manner of provision. A comparison of the number of times gift-giving and other ceremonies were mentioned in the Hun Sen cabinet newsletter Cambodia New Vision and the CPP-friendly Deum Ampil News, Cambodia Express News and Kampuchea Thmey daily online newspapers between October and November 2013, and the same period in 2012, showed that this had increased rather than decreased in the post-election period (Steve Heder, author's personal communication, 10 December, 2013). The recipe for recovery was more and better of the same, rather than a changed strategy. This was clearly because the party reasoned that voters' main priority was to increase the amount of money they could pocket, with little regard for the terms. At the same time, the CPP also made some concessions to address the question of salaries pushed for by the CNRP. Little more than a week following the elections, the CPP announced an increase in basic salaries for civil servants with at least $40 \%$ - to eighty us dollar (though still a far shot from the CNRP's promised 250 Us dollar) to take effect from the first of September (Vong and Worrell 2013). In November, an inter-ministerial committee was formed, tasked with overhauling the salary system of state employees, including civil servants, military, national police, retirees and professional disabled people (Hul 2013).

How are we to understand the current changes in the political landscape? Do they signal a changing political conscience, whereby voters demand better living conditions as a matter of right rather than privileges? Or does the electorate primarily seek to improve its economic status, no matter on what terms?

\section{Everyday Politics of Elections and Emerging Forms of Citizenship}

A useful vantage point from which to approach these questions is offered by everyday interactions between citizens and public authority. The study of everyday politics has typically omitted all that is related to elections, finding 
these far too exceptional. Maintaining that everyday politics cannot possibly be distinguished from the formal politics of electoral contests since discussions about elections, candidates, policies and campaigns are a regular feature of day-to-day life, Andrew Walker (2008) has suggested that we study the 'everyday politics of elections'. This draws attention to how electoral contests are embedded in local social relationships and values that relate to day-to-day politics and spill over into the electoral arena. Walker uses ethnographic fieldwork to trace the popular values that shape judgments about legitimate and illegitimate political power in electoral contexts, and determine why certain candidates are preferred above others. Framing these as a 'rural constitution', he reconceptualizes popular political behaviour that is otherwise dismissed as simply conforming to a patron - client model.

Transforming popular values and practices, which guide interactions with the public authorities, arguably provide a privileged prism with which to conceptualize the vast change in the Cambodian political landscape after the 2013 elections. Several factors which can plausibly be assumed to have contributed to the surge in electoral support for the opposition are bound up with, and feed directly into, a change in everyday relations. Civil servants, military personnel and policemen were attracted by the CNRP's promise of a salary rise - a pledge which promised to transform the very terms of engagement with the population by combatting low-level corruption. Promises of salary rises also attracted the traditional support base of the opposition, particularly garment workers who had migrated to the capital and the rising numbers of overseas workers. Many victims of land-grabbing and evictions, often occurring with unclear legal status and carried out by actors with murky relations to the government, are also believed to have joined the CNRP. ${ }^{12}$ Meanwhile, an increase in social media, Facebook in particular, has created an alternative information outlet, bypassing official channels dominated by the CPP, where public authority can easily be scrutinized and criticized. ${ }^{13} \mathrm{~A}$ larger desire for political change

12 In 2012, the Cambodian League for the Defence and Promotion of Human Rights (LICADHO) estimated around 400,00o Cambodians, out of a total population of 14,3 million to have been affected by land grabs and land disputes since 2003. An ongoing land titling scheme initiated by Prime Minister Hun Sen in 2012 has done little to ease tensions. This scheme can be aptly described as having a twilight character, as it is carried out by youth volunteers funded by the Hun Sen family and the CPP.

13 In March 2013, Cambodia's Ministry of Post and Telecommunications reported 2.7 million internet users, amounting to an internet penetration rate of $18 \%$. The estimated number of Cambodian Facebook accounts in July 2013 was 740,00o, a rapidly growing number. See Suy (2013) and Meyn (2013). 
surfaced, which appeared to be directly centred around relations between the population and political leadership. International influences may have also played their role, with examples ranging from the Arab Spring (routinely used as an example by the CNRP) and the sharp drop in electoral support for the dominant parties in nearby Malaysia and Singapore - two countries which have both served as models for state - society relations for CPP-led governments. ${ }^{14}$

How these changing interactions relate to the legitimacy of competing political party models of provision is a vexed question. At the 2013 meeting of a political discussion group, I chaired a debate on whether the politics of gift-giving has lost its hold as a model of popular political behaviour in Cambodia (Politikoffee meeting, Phnom Penh, 30 November, 2013). The participants were a group of young Cambodians in their twenties, all university students or university graduates employed by NGOS, universities or government bodies. Drawing on their personal experiences from their home provinces, they represented starkly different views that can be broken into three main lines.

The first view held that gift-giving practices are no longer sufficient to gain political allegiance. In view of a blatant discrepancy in living conditions, giftgiving angered, rather than appeased, the electorate. In support of this argument, participants pointed to how the CPP provided gifts to a majority of the population ahead of the elections, yet the vote was almost equal between the CPP and the CNRP. Thus, the election results demonstrated that gift-giving practices have ceased to be effective.

A second line held that gift-giving practices do remain effective for shoring up political support. In the case of the CPP, it was argued, the loss of electoral support reflected that local-level CPP authorities had failed to provide the gifts adequately, and therefore their promises had not been delivered upon. Villagers who had not received any gifts, unlike their peers, chose to punish the CPP at the polls.

A third line similarly held that gift-giving practices remain effective for mobilizing political support in rural Cambodia, and emphasized how this was coupled with security considerations, as not voting for the CPP was perceived as potentially destabilizing. Moreover, a vote for the CNRP could result in the withholding of access to state services. In one participant's words, voters could choose between receiving gifts and threats, or just threats.

14 Hun Sen (interview by the author, 29 August 2011) has cited the policies of Dr Mahathir (prime minister of Malaysia 1981-2003) as an important influence for his rural development and poverty reduction policies. On the rule of law in Singapore as a model for Cambodia under the CPP, see McCarthy and Un (2013). 
Ethnographic evidence demonstrates that these three dynamics are at play at the same time, often interlacing in surprising ways. ${ }^{15}$ Some villagers who joined the CNRP were angered by the CPP-gifts (which typically amounted to a few thousand riels and a sarong), given how their needs were much more dire (pro-CNRP demonstrators, interviews by author and research assistants, Phnom Penh, 15-31 December 2013). Meanwhile, there was also disappointment with the CPP on the part of long-time party supporters, who had lost access to resources they previously enjoyed, and felt unfairly treated by the party. ${ }^{16}$ Such disgruntled voters included victims of land-grabbing in the Phnom Penh communities of Borey Keila and Boeung Kak. When protesting their ordeal, these community members typically carried photos of the top troika of the CPP - Hun Sen, Heng Samrin, and Chea Sim - in a plea for their personal intervention. ${ }^{17}$ Having little to do with the CNRP agenda, this rather reflected the discontent of former CPP supporters who had failed to maintain their access to resources.

Though lacking the rural network of the CPP, the CNRP nevertheless made use of their support base of garment and other workers in Phnom Penh to influence rural constituencies. Workers put financial pressure on relatives in their home provinces, threatening to withhold the remittances that they sent, to ensure that their family members would vote for the CNRP (pro-CNRP demonstrators, interviews by author and research assistants, Phnom Penh, 15-31 December 2013). Their accounts demonstrated a real conflation of motivations. While the workers were primarily motivated by concerns about their livelihoods, these concerns had been put into a coherent political framework of rights-claiming by the political opposition over a longer period of time. Relatives in the home provinces were given a financial incentive to vote for the CNRP, but probably not without political discussion. In these accounts, weariness with gift-giving as a political practice could not be easily separated from displeasure with what was perceived as the inadequate scale of resource provision.

The police and the military are two main support bases where the CPP appears to have lost support. For example, according to the CPP's own estimates, in one district almost half of the soldiers who were expected to vote for

15 This information was collected by the author and eight research assistants in Phnom Penh between November 2013-January 2014, and is made up by discursive interviews with sixty-four CNRP supporters.

16 CPP leaders estimated a narrow majority of CNRP voters to be CPP members. Author's personal communication with senior CPP leaders, November 2013.

17 A practice extolled by Hun Sen; see Kong (2012). 
the party instead voted for the CNRP (CPP working group member, interview by the author, 1 August 2013). Two Radio Free Asia interviews broadcast in the aftermath of elections typify the sources of this discontent. ${ }^{18}$ A policeman, asked why he had come to support the CNRP, declared his dissatisfaction with not making enough to make ends meet, although he had been a policeman and CPP member for decades. The cutting of a portion of his salary for the benefit of the Cambodian Red Cross provided the last straw. In a second interview, a soldier stationed at the Preah Vihear temple on the Thai-Cambodian border similarly pointed to inadequate income. Though he risked his life at the border, his salary remained small, whilst his superiors enjoyed flamboyant lifestyles in the safety of Phnom Penh. In this context, the superiors' occasional visits to the border to hand out small donations of approximately 10,000 riel (2.5 Us dollar) at a time angered, rather than appeased, the soldier. Moreover, whilst this soldier had worked for the armed forces for more than two decades, he had not been able to rise beyond the rank of captain. Famous comedians, however, were enlisted from outside and immediately promoted to high ranks (cf. Wallace 2011). These two accounts show how the quest to secure the right to better income and access to resources, and the rejection of gift-giving practices as inadequate, were entangled. Meanwhile, the CPP's strategy of enlisting popular entertainers to the armed forces in order to boost their popularity had the adverse effect of enraging those left behind.

This development gave the opposition the impression that the CPP's hold on power, backed up by their hitherto unwavering grip over the national security apparatus, could be seriously challenged. The conflation between the CPP and the state means that security institutions have largely functioned as an extension of the party. ${ }^{19}$ In the aftermath of the elections, the CNRP repeatedly urged police and military to take the side of demonstrators and demand a change of government (see, for example, Neou and Peter 2013). The CNRP also encouraged such expectations in order to assure supporters and demonstrators of their safety. For example, images of CNRP security staff unprecedentedly sitting down together with police at Freedom Park were widely circulated in social media. However, starting from early January 2014, such hopes were dashed as garment worker demonstrations, supported by the CNRP, were countered by deadly police violence, which was then followed by a general crackdown on oppositional activities and a ban on assembly.

\footnotetext{
18 Radio Free Asia news broadcasts, August 2013.

19 For example, in the run-up to the 2013 elections, the armed forces and police openly campaigned for the CPP. See Human Rights Watch (2013).
} 
This crackdown, still ongoing at the time of writing in February 2014, has thrown the twilight character of security into sharp relief, as well as the political ends that it serves. In the repression of dissent that unfolded over January 2014, municipal and district security guards were called in alongside regular security forces to enforce the ban on assembly by violently clamping down on demonstrations. This practice came under fierce criticism by the media and representatives of civil society, who maintained that the security guards were not legally mandated to assume this task. Critics believed that the rationale of the practice was to allow the government to maintain deniability, keeping itself at arm's length from the violence in order to escape direct blame for unpopular acts (see, for example, Meyn and Aun 2014). In response, government spokesman Phay Siphan ambiguously clarified that such individuals were hired by Phnom Penh City Hall from private security firms, and that the authorities referred to them as 'police agents' (Pye and Khouth 2014).

Known as sândap thnoap, these security guards in fact form a branch of the municipal and district police, and are responsible for the maintenance of public order. They have the authority to carry weapons if they are authorised by the judicial police, and are legally bestowed coercive power when public order is disturbed. While newspapers and NGOs deplored how these forces pretended to have legal authority to use force when in fact they lacked it in reality, the dynamic was the very opposite - these forces' use of violence was legally sanctioned, yet portrayed as legally ambiguous. Rather than using their official uniforms, the security guards showed up to demonstrations wearing red scarves and motorbike helmets - a practice arguably intended to make them appear anonymous and unaccountable.

In a converse manner, this very likely served the very same purpose as that singled out by the critics: by refraining from clarifying the legal mandate of these officers, the government could keep its distance from ongoing violence. At the height of political tension in December 2013, shortly before violence erupted, Prime Minister Hun Sen warned people to 'beware of the third hand', provoking rife speculation over who this might refer to. Some observers considered it a threat to employ agent provocateurs to stir up violence, which would then justify a harsh government response. As the crackdown started, the scores of young male security guards lacking official designation were quickly equated with such a third hand. ${ }^{20}$ The very discourse of the 'third hand'

20 Given the purposely secretive nature of these forces, it cannot be excluded that outside individuals lacking legal authority are also enlisted. Yet, the core of these forces appears to be formed by the sândap thnoap. The main point of the third hand policy is precisely this: that the public may not know who the forces are made up of. 
underscores the political expediency of maintaining confusion as to the legal mandate of public authority, and offers an interesting example of the purposeful 'twilighting' of security by the government.

A range of institutions with fuzzy mandates, in fact, exercise public authority when providing security. For example, our lunch host (introduced at the opening of this chapter), who provides security at Phnom Penh's O'Russey market, also holds the title of sândap thnoap. More commonly, however, he simply refers to himself as a security guard (sântesokh or yeam). Sambath is employed by O'Russey market, which is in turn charged by Phnom Penh City Hall with the hiring of security personnel. A majority of security staff at O'Russey market are employed under this form of contract, which demonstrates the twilight character of the provision of market security. The market is semi-autonomous, yet exercises public authority in assuming state qualities of governance. Though a few of Sambath's colleagues are police cadres directly employed by the municipality, this form of contract typically requires one to have worked at the market for more than a decade, and excludes those who like Sambath - have family or other ties to opposition parties.

O'Russey market vividly illustrates the politicization of twilight institutions in Cambodia, as well as the possibilities these offer for everyday values and practices to be renegotiated between citizens and public authorities. Among the largest markets in Phnom Penh, O'Russey houses several floors and is frequented by residents from across the city. Market security is organized in a pyramidal structure - it is headed by a market committee with five to six members, presided over by a director and a deputy director. The market committee sits on top of four divisions (mondol) with 20-22 staff members each, each of which is in turn divided into three teams (krum). During the time that a power-sharing formula was in place in government between CPP and FUNCINPEC (from 1993 to 2008), a quota system also operated for this structure - though not strictly state - with a certain number of the staff belonging to the CPP and FUNCINPEC respectively. Upon the disintegration of FUNCINPEC, following the 2006 ouster of Ranariddh as party president, all security staff were required to submit a request to join the CPP in order to retain their employment. The president of the market, Kieng Leak, is an in-law of Chea Sophara, former CPP mayor of Phnom Penh.

The twilight character of market security has helped the CPP to integrate sections of it as an important, covert part of the party security apparatus. Forming a special unit of sorts, around forty security guards (sândap thnoap) from O'Russey are regularly employed for counter-demonstrations in and around Phnom Penh - invariably appearing in civilian clothes. Such events include garment worker demonstrations, protests over land evictions, and, 
allegedly, the force's involvement in protests against CNRP leader Kem Sokha ahead of the July 2013 elections, as well as a September 2013 attack against antieviction activists, with close ties to the CNRP, at Phnom Penh's Wat Phnom (O'Russey market security guards, interviews by the author, Phnom Penh, December 2013). This force was also employed to enforce the ban on assembly at Phnom Penh's Freedom Park in January 2014, when demonstrators were forcefully prohibited from entering the area (O'Russey market security guards, interviews by the author, Phnom Penh, January 2014). Though these security guards normally work side by side with other market security guards, their tasks go far beyond those of their peers.

The economic arrangement at the market has sown discontent among many of the other security guards. Guards have dual sources of income - firstly, they raise a monthly salary of 90,00o riel (22.50 us dollar) and, in addition, vendors pay a monthly fee of 20,000 riel (five us dollar) per stand (luy yeam), of which the security guard keeps about $70 \%$, passing on the remaining $30 \%$ to the market committee. Whilst the exact sum is negotiable, a lower-level security staff typically keeps about $300,000-350,000$ riel $\left(75^{-87.50}\right.$ us dollar) per month. Senior guards earn more, averaging a total income of 200 us dollar per month. Out of the luy yeam that is passed to the market committee, donations are given to support, in particular, pro-CPP newspapers. The market leaders also detract 3000 riel ( 0.75 us dollar) per month from the salary of each security guard as a donation to the Cambodian Red Cross. Amounting to but a small amount of money, the main purpose of this practice is arguably to increase the membership number of the CRC, as a donation automatically bestows membership. Security guards are also requested to donate 3000 riels each to the CPP annual 7 January celebration, which they are brought to celebrate at Phnom Penh's Olympic Stadium. Security guards interviewed expressed their annoyance at these practices, citing them as reasons for covertly supporting the CNRP.

The twilight character of market security also facilitates the renegotiation of relations between security and vendors, providing a potential challenge to the status quo. The government has long controlled the market place, keeping a close eye upon known opposition supporters among vendors. At O'Russey, security guards are tasked with monitoring and managing vendors' political inclinations and are required to keep statistics of the vendors' political allegiance. They are expected to circulate and listen to the vendors' conversations and take note of what radio channels they listen to. This information is then used to identify supporters of the CPP and of the CNRP - lists of which are passed on to the market committee, which are said to be kept for internal use 
at the market. ${ }^{21}$ In the run-up to and aftermath of the July 2013 elections, these practices began to crack. Though all security guards at O'Russey outwardly support the CPP, this says little about what proportion of support is truly heartfelt, and the guards' easy switch to private roles makes it easier for them to engage in earnest discussion with vendors. The security guards estimated around only $20-30 \%$ of the guards to be loyal to the CPP (O'Russey market security guards, interviews by the author, Phnom Penh, January 2014). By contrast, market vendors appreciated approximately 90\% of vendors to support the CNRP (O'Russey market vendors, interviews by the author, Phnom Penh, December 2013).

The security guards and vendors interviewed described their relations before the elections as generally mutually suspicious, with little open discussion. Politics was a taboo subject and thus rarely ventured upon. After the elections, however, interactions between vendors and security guards changed dramatically. The surge in electoral support for the opposition opened up public discourse and emboldened voices of dissent. According to several security guards, vendors now dared to express their political views in discussions, and even openly listened to the often government-critical Radio Free Asia at their market stands. In the plain words of one security guard, 'vendors now dare to state their opinions freely'. Though security guards generally remain more cautious than vendors, both groups reported that it had become more frequent for lower echelon guards and vendors to communicate openly with each other, converging on their criticism of the economic arrangements at the market. Such interactions necessarily took place beyond the hearing reach of higherlevel market authorities, and one guard confided, 'Whereas before I never spoke to vendors about politics, we now frequently discuss current events, but we have to speak in secret' (O'Russey security guard, interviews by the author, Phnom Penh, December 2013).

Changing interactions like these are by no means unidirectional, nor are they universal and, in light of the uncertainty surrounding future political developments, could just as easily and swiftly be reversed. At Phnom Penh's Central Market, vendors reported being prohibited by security guards from exiting the market to witness Sam Rainsy's return, and video cameras were placed around the market to identify those who left to welcome him nonetheless (Phak and McMorran 2013).

21 Such practices have been reported from across the capital's markets. For example, vendors at Phnom Penh's Central Market stated that those among them known to be opposition supporters faced constant harassment. See Phak and McMorran 2013. 
Changing interactions between citizens and public authority can be studied in terms of these ongoing negotiations at the market that produce divergent outcomes. These range from security guards preventing vendors from attending the opposition leader's return rally, to guards furtively making friendship with vendors and then obtaining the video of said rally from them, to the covert employment of yet another group of guards to break up post-election demonstrations.

\section{Conclusion}

The securing of benefits, welfare and access to state resources is central for emerging conceptions of citizenship and democracy in Cambodia. Previous scholarly works, recognizing the centrality of provision for relations between populations and public authority in many national contexts in the Global South, has typically treated citizenship and clientship as necessary opposites either seeking to positively re-evaluate the pursuit of exceptional entitlements in a gift-giving economy (Chatterjee 2004, 2011; Walker 2008, 2012), or finding clientship to be rejected outright by populations aspiring for full citizenship rights (for example, Hughes (2006) charges that contemporary gift-giving practices lack any kind of cultural legitimacy in Cambodia). However, ongoing change in Cambodia challenges such a clear-cut distinction. Treating citizenship and clientship as mutually exclusive opposites fails to address the vast landscape of movements between these two conditions - where crucial things can happen. The popular perceptions and practices of accessing resources and welfare by right, and having this access mediated by personal relationships, can overlap substantially at times so that citizenship and clientship are best understood as blurred and potentially overlaying notions (cf. Robins et al., 2008). These different perceptions can also collapse and transform into each other. An initial push for improved living conditions has, for some, turned into a rejection of clientship and the yearning to secure rights.

Twilight institutions run like a red thread through these negotiations, exercising de facto public authority in key areas, ranging from the provision of developmental assistance to emergency relief and security. Two characteristics stand out in the Cambodian context: Firstly, it is through these institutions that the very quality and meaning of Cambodian democratic citizenship is being negotiated. Secondly, instances of what appears to be the purposeful attempt to keep the legal mandate of public authority ambiguous alert us to the political expediency inherent to twilight ambiguity.

A focus on these institutions allows us to discern changing dynamics in the relations between Cambodian citizens and public authorities that typically 
remain out of the spotlight. Interactions between ordinary people and institutions such as the Cambodian Red Cross, or everyday negotiations between market vendors and security staff who straddle the public and private divide, betray changing political perceptions and practices that are at the very centre of current goings-on. Facing economic hardships, some voters were infuriated by having to contribute to the funding of the $\mathrm{CRC}$ - one important channel of provision. Likewise, market vendors complained about how the money they had provided for market security was passed on to pro-CPP causes. In the words of Lund (2006:682), 'While the twilight has an opaque character, ... this is when and where politics 'happens'. If they do not amount to the proverbial double-edged sword, these twilight aspects certainly have the potential for generating divergent outcomes. Most sinisterly, the twilight nature of security was employed to facilitate the crackdown on post-election dissent. At the same time, the twilight character of these institutions also allowed ordinary people to transform their relations to public authority. Moving in and out of the public and private spheres, market security guards were more easily approached and interacted on more sincere terms with ordinary people. This change was potentially subversive as it compromised the guards' role of monitoring vendors' political allegiance. Emboldened by the closeness this afforded, one vendor would even give a DVD of Sam Rainsy's return to Phnom Penh to our host for our surprised lunch company to watch.

\section{References}

Chandler, D. (1991). The tragedy of Cambodian history: Politics, war and revolution since 1945. New Haven, CT; London: Yale University Press.

Chatterjee, P. (2004). The politics of the governed: Reflections on popular politics in most of the world. New York: Columbia University Press.

Chatterjee, P. (2011). Lineages of political society: Studies in postcolonial democracy. New York: Columbia University Press.

Connors, M. (2003). Democracy and national identity in Thailand. London: Routledge Curzon.

Corfield, J. (1994). Khmers stand up!: A history of the Cambodian government 1970-1975. Clayton, VIC: Centre of Southeast Asia, Monash University.

Frings, V. (1995). The Cambodian People's Party and Sihanouk.Journal of Contemporary Asia, 25(3), 356-365.

Heder, S. (1995). Cambodia's democratic transition to neoauthoritarianism. Current History, 94(596), 425-429.

Hughes, C. (2001). Transforming oppositions in Cambodia. Global Society, 15(3), $295^{-318 .}$ 
Hughes, C. (2002). Parties, protest and pluralism in Cambodia. Democratization, 9(3), $165^{-186 .}$

Hughes, C. (2006). The politics of gifts: Generosity and menace in contemporary Cambodia. Journal of Southeast Asian Studies, 3r(3), 469-489.

Hughes, C. (2009). Reconstructing legitimate political authority through elections? In J. Öjendal \& M. Lilja (Eds.), Beyond democracy in Cambodia: Political reconstruction in a post-conflict society (pp. 31-69). Copenhagen: NIAS Press.

Hul, R. (2013, November 28). Government prepares civil service pay overhaul. The Cambodia Daily. Retrieved from http://www.cambodiadaily.com.

Human Rights Watch. (2013, July 22). Cambodia: Army, police campaign for ruling party. Retrieved from http://www.hrw.org.

Hun, S. (1991). 13 tosâvot nei domnaoer Kampuchea [13 decades of Cambodia's evolution]. Phnom Penh: Pracheachon.

Hun, S. (2005). Selected comments at the graduation and presentation of diploma to the graduates from the Asia-Europe Institute. Cambodia New Vision, go.

Hun, S. (2007). Keynote address at the opening ceremony of the Samdech Hun Sen's tree nursery station at Takeo's Phnom Tamao. Cambodia New Vision, 117.

Kong, S. (2012, March 16). Hun Sen extols use of his photograph by protestors. VOA Khmer. Retrieved from http://www.voacambodia.com.

Lund, C. (2006). Twilight institutions: Public authority and local politics in Africa. Development and Change, 37(4), 685-705.

McCarthy, S., \& Un, K. (2013). Rule of law without democratization: Cambodia and Singapore in comparative perspective. Unpublished draft.

Men, N.S., \& Dickens, T. (2005). United for humanity. Phnom Penh: Cambodian Red Cross, International Committee of the Red Cross and the Federation.

Meyn, C. (2013, November 11). Virtual democracy. Southeast Asia Globe. Retrieved from http://www.sea-globe.com.

Meyn, C., \& Aun, P. (2014, January 7). Government finds deniability in district security force. The Cambodia Daily. Retrieved from http://www.cambodiadaily.com.

Neou, V., \& Peter, Z. (2013, August 13). Sam Rainsy rejects accusations of inciting military coup. The Cambodia Daily. Retrieved from http://www.cambodiadaily.com.

Norodom, R. (1998). Droit public cambodgien. [Perpignan]: CERJEMAF/Presses Universitaires de Perpignan.

Öjendal, J., \& Lilja, M. (2009). The never-ending hunt for political legitimacy in a post-conflict context. In J. Öjendal \& M. Lilja (Eds.), Beyond democracy in Cambodia: Political reconstruction in a post-conflict society (pp. 297-312). Copenhagen: NIAS Press.

Pak, K., Horng, V., Eng, N., Ann, S., Kim, S., Knowles, J., \& Craig, D. (2007). Accountability and Neo-Patrimonialism in Cambodia: A Critical Literature Review. Phnom Penh: Cambodia Development Resource Institute. 
Phak, S., \& McMorran, M. (2013, July 22). Vendors made to toe party line. Phnom Penh Post. Retrieved from http://www.phnompenhpost.com.

Pye, D., \& Khouth, S. (2014, January 22). Ban foes undeterred. Phnom Penh Post. Retrieved from http://www.phnompenhpost.com.

Robins, S., Cornwall, A., \& von Lieres, B. (2008). Rethinking 'citizenship' in the postcolony. Third World Quarterly, 29(6), 1069-1086.

Sam, R. (2008). Des racines dans la pierre: Mon combat pour la renaissance du Cambodge. Paris: Calmann-Lévy.

Sam, R. (2013, December 10). International Human Rights day speech, presented in Phnom Penh.

Slocomb, M. (2006). The nature and role of ideology in the modern Cambodian state. Journal of Southeast Asian Studies, 37(3), 375-395.

Suy, H. (2013, March 25). Cheap data, better tech putting more Cambodians online. Voice of America. Retrieved from http://www.voanews.com.

Thompson, A. (2004). The suffering of kings: Substitute bodies, healing, and justice in Cambodia. In J. Marston \& E. Guthrie (Eds.), History, Buddhism, and new religious movements in Cambodia (pp. 91-112). Honolulu, HI: University of Hawaii Press.

Un, K. (2005). Patronage politics and hybrid democracy: Political change in Cambodia, 1993-2003. Asian Perspective, 29(2), 203-230.

Vong, S., \& Worrell, S. (2013, August 8). Civil servants to see raise. Phnom Penh Post. Retrieved from http://www.phnompenhpost.com.

Walker, Andrew. (2008). The rural constitution and the everyday politics of elections in northern Thailand. Journal of Contemporary Asia, 38(1), 84-105.

Walker, Andrew. (2012). Thailand's political peasants: Power in the modern rural economy. Madison, Wisconsin: University of Wisconsin Press.

Wallace, J. (2011, June 15). In Cambodia, comedians double as government propagandists. The Atlantic. Retrieved from http://www.theatlantic.com. 